\title{
Immune modulation by virus-encoded secreted chemokine binding proteins
}

\author{
Haleh Heidarieh, Bruno Hernáez, Antonio Alcamí* \\ Centro de Biología Molecular Severo Ochoa (Consejo Superior de Investigaciones Científicas - Universidad Autónoma de Madrid), Cantoblanco,
} Madrid, Spain

\section{A R T I C L E I N F O}

Article history:

Available online 17 March 2015

\section{Keywords:}

Chemokines

Chemokine binding proteins

Poxviruses

Herpesviruses

Immune evasion

Glycosaminoglycans

\begin{abstract}
A B S T R A C T
Chemokines are chemoattractant cytokines that mediate the migration of immune cells to sites of infection which play an important role in innate and adaptive immunity. As an immune evasion strategy, large DNA viruses (herpesviruses and poxviruses) encode soluble chemokine binding proteins that bind chemokines with high affinity, even though they do not show sequence similarity to cellular chemokine receptors. This review summarizes the different secreted viral chemokine binding proteins described to date, with special emphasis on the diverse mechanisms of action they exhibit to interfere with chemokine function and their specific contribution to virus pathogenesis.
\end{abstract}

(C) 2015 Elsevier B.V. All rights reserved.

\section{Introduction}

Viral infection stimulates the production of cytokines and chemokines that trigger an immune response that can eliminate the invading virus. Interferons (IFNs) and tumor necrosis factor (TNF) are cytokines that induce anti-viral states or apoptosis within the innate immune response (Biron, 2001; Guidotti and Chisari, 2000). Chemokines are chemotactic cytokines that play a crucial role in inducing the migration of immune cells to areas of infection (Baggiolini, 1998). They are classified into four classes: C, CC, CXC and $\mathrm{CX} 3 \mathrm{C}$ chemokines according to the position of the $\mathrm{N}$-terminal cysteine residue(s) (Zlotnik and Yoshie, 2000). Chemokines are secreted from the cell and immobilized on the cell surface through their interaction with glycosaminoglycans (GAGs) and establish a concentration gradient that is important to direct leukocytes

Abbreviations: CKBP, chemokine binding protein; CPXV, cowpox virus; $\mathrm{Crm}$, cytokine response modifier; ECTV, ectromelia virus; GAGs, glycosaminoglycans; GPCR, G-protein coupled receptor; HSV, herpes simplex virus; IFN, interferon; IFN $\gamma$ $\mathrm{R}$, interferon gamma receptor; MHV-68, murine gammaherpesvirus 68; MYXV, myxoma virus; ORFV, orf virus; SCP, secret domain containing protein; gG, glycoprotein G; SgG, secreted portion of gG protein; SECRET, smallpox virus encoded chemokine receptor; TNF, tumor necrosis factor; TNFR, tumor necrosis factor receptor; VACV, vaccinia virus; VARV, variola virus; WR, strain Western Reserve.

* Corresponding author at: Centro de Biología Molecular Severo Ochoa (Consejo Superior de Investigaciones Científicas - Universidad Autónoma de Madrid), Nicolás Cabrera 1, Cantoblanco, 28049 Madrid, Spain. Tel.: +34 911964569; fax: +34 911964420 .

E-mail address: aalcami@cbm.csic.es (A. Alcamí). to sites of infection (Handel et al., 2005; Johnson et al., 2005). Immune cells are activated through specific high affinity interactions between chemokines and the G-protein coupled receptors (GPCRs) (Blanpain et al., 2003; Proudfoot, 2002; Zlotnik et al., 2006) (Fig. 1A). The three-dimensional fold of all monomeric chemokines is conserved. The N-loop is followed by a $3_{10}$ helix, the three $\beta$ strands form a $\beta$-pleated sheet and these are connected by the 30 's and 40's loops. The 50's loop connects the last secondary structural, a C-terminal $\alpha$-helix (Fernandez and Lolis, 2002) (Fig. 2A). Chemokines interact with GPCRs and GAGs through distinct binding sites that may overlap.

Poxviruses and herpesviruses are large DNA viruses that dedicate a great part of their genetic information to escape and modulate the host immune response (Finlay and McFadden, 2006; Seet et al., 2003a). Variola virus (VARV), a member of the poxvirus family, was the causative agent of smallpox, one of the most virulent human diseases (Smith and McFadden, 2002), and vaccinia virus (VACV) is the vaccine used to eradicate smallpox by 1980. Ectromelia virus (ECTV) causes a smallpox-like disease in mice, cowpox virus (CPXV) is a rodent virus of broad host range that causes sporadic infections in other mammals, and myxoma virus (MYXV) causes myxomatosis in rabbits. Animal infections with VACV, ECTV, CPXV and MYXV are used as models to study poxvirus pathogenesis and their interaction with the immune system. The herpesvirus family includes important human pathogens such as herpes simplex virus (HSV), varicella zoster virus or cytomegalovirus.

Poxviruses and herpesviruses have evolved a variety of mechanisms to evade their destruction by the host immune system. One 


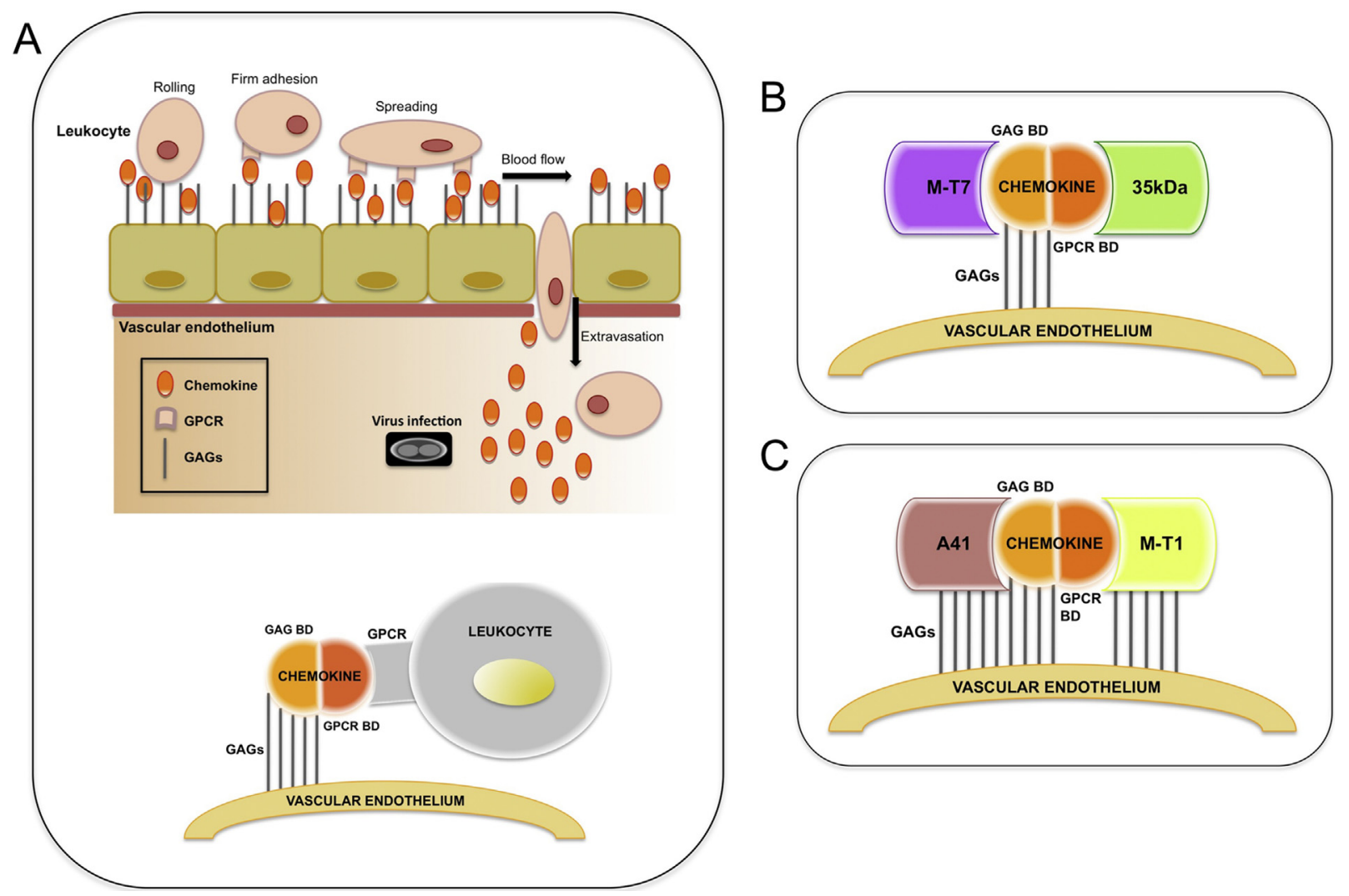

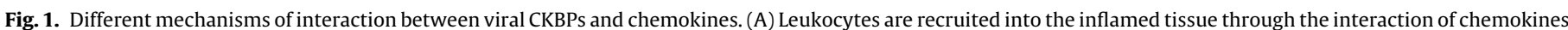

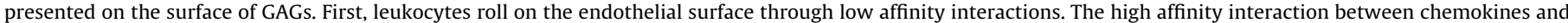

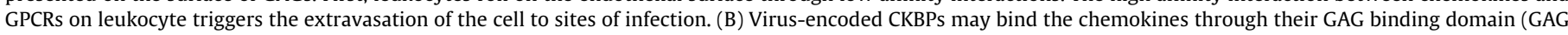
BD) or their GPCR binding domain (GPCR BD), (C) Viral CKBPs may simultaneously interact with GAGs to anchor the CKBP to the cell surface.

of these strategies is the expression of proteins that interfere and modulate the chemokine system, including viral chemokine homologues, viral chemokine receptor homologues and viral chemokine binding proteins (CKBPs) (Alcami, 2003; Alcami and Koszinowski, 2000). CKBPs are secreted proteins with no sequence similarity to their cellular counterparts and can interrupt the chemokine function via distinct mechanism of action, abrogating the formation of the chemokine gradient or the interaction between chemokines and their specific cellular receptor (Fig. 1B and C). CKBPs have been found in non-viral pathogens such as the trematode

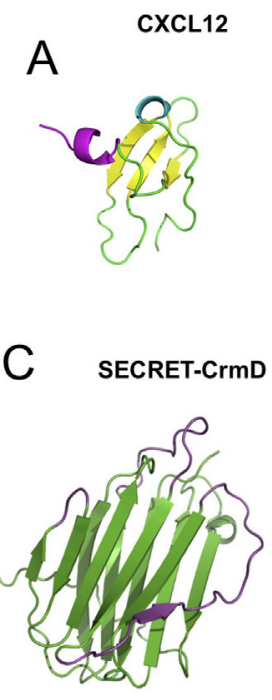

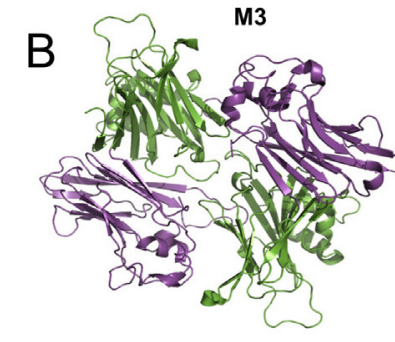

35-kDa

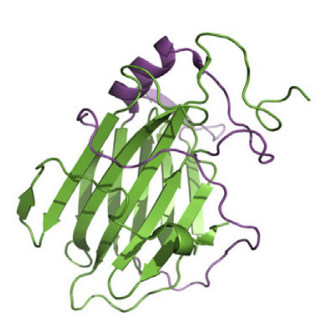

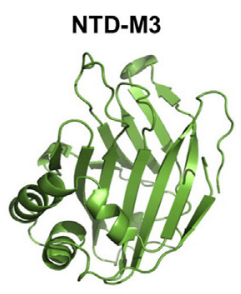

A41

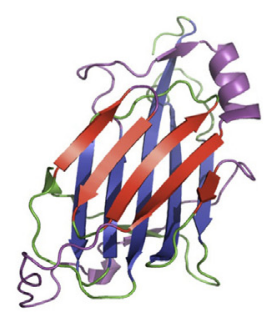

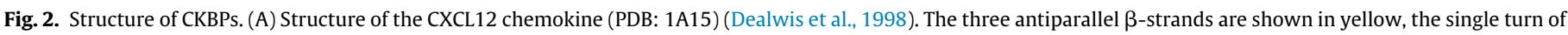

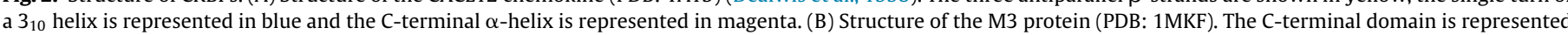

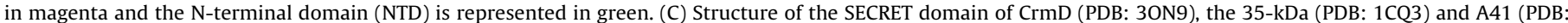

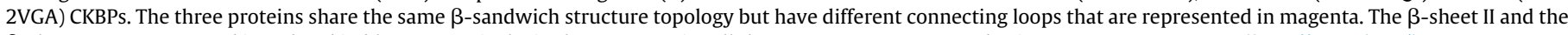
$\beta$-sheet I are represented in red and in blue, respectively, in the A41 protein. All the structures were created using Open-Source PyMOL (http://pymol.org/). 
Schistosoma mansoni (Smith et al., 2005) and ticks (Deruaz et al., 2008; Frauenschuh et al., 2007). More recently, a human soluble CKBP has been described (Dyer et al., 2014).

We focus this review on the mechanism of action of the virusencoded CKBPs and their role in immune evasion and pathogenesis.

\section{Poxvirus}

\subsection{The poxvirus $35-k D a$ protein}

The major secreted protein of $35 \mathrm{kDa}$ encoded by VACV strains Lister and rabbitpox was identified as a CKBP that inhibits CC chemokine activity (Alcami et al., 1998; Graham et al., 1997; Smith et al., 1997) (Table 1). This protein is expressed by many poxviruses, including VARV, CPXV, ECTV and MYXV. The 35-kDa protein has been shown to bind with high affinity (in the low nanomolar range) to nearly all human and mouse CC chemokines (Burns et al., 2002). Low affinity binding to CXCL1 and CXCL8 has been detected, but it has not been possible to demonstrate binding to a range of other CXC, C or CX3C chemokines (Alcami et al., 1998; Burns et al., 2002; Lalani et al., 1998; Smith et al., 1997). The mechanism of action of the 35-kDa CKBP is competitive inhibition of CC-chemokine binding to cellular receptors (Fig. 1B), inhibiting their ability to induce signal transduction and cell migration in vitro assays (Alcami et al., 1998; Lalani et al., 1998; Smith et al., 1997). The 35-kDa protein of MYXV also called M-T1, has the unique ability to interact with GAGs and with chemokines simultaneously (Seet et al., 2001), allowing the retention of the protein in the vicinity of infected cells and may enhance its ability to protect the sites of infection from chemokinemediated anti-viral responses (Fig. 1C).

The three dimensional structure of several 35-kDa CKBPs have been described to date. The structure of the CPXV 35-kDa CKBP was determined by X-ray crystallography, and it was shown to be a compact globular protein with a unique sandwich topology (Fig. 2C). The $\beta$-sandwich domain is composed of two $\beta$-sheets, parallel to each other, two short $\alpha$-helices, and a few large loops connecting these secondary elements (Carfi et al., 1999). A patch of conserved negatively charged residues on the exposed face of $\beta$-sheet II were suggested as a chemokine-binding site. The structure of 35-kDa of ECTV was reported later and confirmed the general sandwich folding of this family of CKBPs (Arnold and Fremont, 2006). The residues in the CKBP that are essential in the interaction with the CCL2 and CCL3 chemokines was determined by mutagenesis and showed that are localized at the $\beta$-sheet II and in the $\beta 2-\beta 4$ loop. Further structural studies in solution by nuclear magnetic resonance determined the structure of 35-kDa VACV strain rabbitpox and human CCL4 complex. This study confirmed that the $35-\mathrm{kDa}$ CKBP uses residues from the $\beta$-sheet II to interact with surface of the chemokine that includes residues adjacent to its N-terminal region, as well as residues in the 20's region and the 40's loop (Zhang et al., 2006) and established the structural basis for the ability of this CKBP to promiscuously recognize CC chemokines. These results confirmed the previous binding studies with CCL2 mutants that identified the amino acid residues required for high affinity interaction with the VACV 35-kDa CKBP which were similar to those involved in CCL2-CCR2b chemokine receptor binding (Beck et al., 2001; Seet et al., 2001). The structural insights into the interaction between 35-kDa and CCL11 complex studied by nuclear magnetic resonance and fluorescence anisotropy are similar to those of the $35-\mathrm{kDa}$ and CCL4 complex. The $\beta$-sheet II and the highly positive and quite flexible loop between the $\beta-2$ and $\beta-3$ strands exhibit interactions with the N-loop, 20's region, 40's loop and the third $\beta$ strand of CCL11. The 35-kDa protein recognizes epitopes that are relatively rigid and conserved among CC chemokines (Kuo et al., 2014).
In order to know the role of this CKBP in viral pathogenesis various laboratories constructed recombinant viruses to inactivate the $35-k D a$ gene. Insertional mutation of the $M-T 1$ gene in MYXV had no significant effects on disease progression or in the overall mortality rate of infected rabbits but increased the infiltration of leukocytes in primary infection sites during the initial 2-3 days of infection (Lalani et al., 1999). Similar conclusions have been shown in mice infected with a mutant rabbitpox virus, a VACV strain, in which the $35 \mathrm{kDa}$ gene was inactivated (Graham et al., 1997). The same rabbitpox virus mutant appeared to induce an earlier onset of symptoms and more severe illness at sub-lethal doses than wild type virus (Martinez-Pomares et al., 1995). The expression of the 35-kDa protein from VACV strain Western Reserve (WR), a strain that does not encode the CKBP, caused a slight attenuation of the virus associated with reduced inflammatory pathology in the lungs, suggesting that this CKBP may attenuate the immune-mediated pathology caused by VACV infection (Reading et al., 2003).

Some reports have demonstrated the potential therapeutics effects of the 35-kDa protein in inflammatory diseases such as atherosclerosis (Bursill et al., 2009) or arthritis (Buatois et al., 2010). In another study, a series of novel 35-kDa-Fc fusion proteins were constructed, and one of these mutant proteins shows increased potency of CC chemokine blockade and enhanced antiinflammatory activity (White et al., 2011).

\subsection{The A41 family of poxvirus CKBPS}

VACV A41 is an immunomodulatory protein that is expressed early and late during infection and is highly conserved among poxviruses. The A41 glycoprotein shares sequence similarity to the 35-kDa CKBP from VACV and other poxviruses (Ng et al., 2001). Two different groups carried out an extensive screening of chemokines by surface plasmon resonance for their potential binding to recombinant A41 from ECTV (E163) and VACV, and they reported the identification of a reduced set of CC and CXC chemokines that interacts with the A41 protein with high affinity (Bahar et al., 2008; Ruiz-Arguello et al., 2008) (Table 1). In contrast to the poxvirus 35-kDa CKBP, the interaction of A41 with chemokines is inhibited in the presence of GAGs and the A41 protein does not block cellular migration induced by chemokines in vitro. By using mutant forms of CXCL10 and CXCL12 $\alpha$ chemokines with reduced ability to interact with chemokine receptors or GAGs, it was shown that the ECTV E163 protein interacts with the GAG-binding domain of chemokines (Ruiz-Arguello et al., 2008). It was suggested that the inhibition of leukocyte migration in vivo may be related to the ability of A41 to block the correct interaction of chemokines with GAGs, which is required for appropriate chemokine function in vivo (Handel et al., 2005; Johnson et al., 2005). In addition to its interaction with chemokines, the ECTV E163 CKBP can also interact with high affinity with GAGs, enabling E163 to attach to cell surfaces and to remain in the vicinity of the sites of viral infection (Fig. 1C).

Despite sharing only approximately $20 \%$ sequence identity with the 35-kDa CKBP, the crystal structure of the A41 protein revealed a globular $\beta$-sandwich domain similar to that of the $35-\mathrm{kDa}$ CKBP family (Bahar et al., 2008) (Fig. 2C), but it has notable structural differences particularly in surface loops and electrostatic charge distribution. The highly acidic loop between strands 2 and 4 present in the $35-\mathrm{kDa}$ CKBP is absent in the $\mathrm{A} 41$ protein and may restrict the selectively of the A41 protein to only a few chemokines. Although the A41-chemokine complex has not been crystallized, structural modeling suggested that the interaction of A41 and 35-kDa proteins with chemokines involves the same domains (Bahar et al., 2008). The A41 and 35-kDa CKBPs from poxviruses are structurally related but block the chemokine system in different but complementary ways (Fig. 1B and C), which is advantageous for the virus to control the host anti-viral responses. 
Table 1

CKBPs encoded by viruses: structure, binding properties and contribution to virulence.

\begin{tabular}{|c|c|c|c|c|c|}
\hline СКBP & Species & $\begin{array}{l}\text { CKs and mechanism of } \\
\text { action }\end{array}$ & Deletion mutant phenotype & Structure/PBD & References \\
\hline \multicolumn{6}{|l|}{ Poxvirus } \\
\hline 35-kDa & $\begin{array}{l}\text { ECTV, CPXV, } \\
\text { VACV, MYXV }\end{array}$ & $\begin{array}{l}\text { Binds CC chemokines, } \\
\text { preventing interaction } \\
\text { with specific receptors. } \\
\text { Inhibits cell migration. } \\
\text { MYXV MT1 also interacts } \\
\text { with GAGs of cellular } \\
\text { surface. }\end{array}$ & $\begin{array}{l}\Delta 35 \mathrm{kDa}-\mathrm{RPXV} \text { : ID infection of } \\
\text { rabbits. Increased leukocyte } \\
\text { infiltration during the early } \\
\text { phases of infection. } \\
\frac{\Delta 35 \mathrm{kDa}-\mathrm{RPXV} \text { : IN infection of }}{\text { mice. An earlier onset and }} \text { more severe illness at } \\
\text { sub-lethal doses. } \\
\text { ID infection of rabbits, no } \\
\text { differences. } \\
\Delta \text { MT1-MYXV: ID infection of } \\
\text { rabbits, increase in infiltrating } \\
\text { leukocytes at the primary site } \\
\text { of virus inoculation. }\end{array}$ & $\begin{array}{l}\text { 35-kDa CPXV: 1CQ3 } \\
\text { 35-kDa ECTV: 2GRK } \\
\text { 35-kDA VACV/CCL4 (complex): 2FFK }\end{array}$ & $\begin{array}{l}\text { Alcami et al. } \\
\text { (1998), Arnold and } \\
\text { Fremont (2006), } \\
\text { Burns et al. (2002), } \\
\text { Carfi et al. (1999), } \\
\text { Graham et al. } \\
\text { (1997), Lalani et al. } \\
\text { (1998, 1999), } \\
\text { Martinez-Pomares } \\
\text { et al. (1995), Seet } \\
\text { et al. (2001), Smith } \\
\text { et al. (1997) and } \\
\text { Zhang et al. (2006) }\end{array}$ \\
\hline CBP & ORFV & $\begin{array}{l}\text { Binds CC and C chemokines } \\
\text { through their receptor } \\
\text { binding domain. Inhibits } \\
\text { chemokine signaling. }\end{array}$ & ND & ND & Seet et al. (2003a,b) \\
\hline A41 & VACV, ECTV & $\begin{array}{l}\text { Binds CC and CXC } \\
\text { chemokines through their } \\
\text { GAG binding domain. } \\
\text { Interacts with cell surface } \\
\text { GAGs. } \\
\text { Does not inhibit } \\
\text { chemotaxis in vitro. }\end{array}$ & $\begin{array}{l}\triangle \mathrm{A} 41 \mathrm{~L}-\mathrm{VACV} \text { : ID infection of } \\
\text { mice. More severe lesions } \\
\text { than wild type virus. } \\
\triangle \mathrm{A} 41 \mathrm{~L}-\mathrm{VACV} \text { : IN infection of } \\
\text { mice. Mice lost more weight } \\
\text { than those infected with wild } \\
\text { type virus. }\end{array}$ & A41-VACV: 2VGA & $\begin{array}{l}\text { Bahar et al. (2008), } \\
\text { Clark et al. (2006), } \\
\text { Ng et al. (2001) and } \\
\text { Ruiz-Arguello et al. } \\
\text { (2008) }\end{array}$ \\
\hline M-T7 & MYXV & $\begin{array}{l}\text { Binds C, CC and CXC } \\
\text { chemokines through their } \\
\text { GAG binding domain. }\end{array}$ & $\begin{array}{l}\Delta \text { MT7-MYXV: Attenuated in } \\
\text { rabbit infections. }\end{array}$ & ND & $\begin{array}{l}\text { Lalani et al. (1997) } \\
\text { and Mossman et al. } \\
\text { (1996) }\end{array}$ \\
\hline SECRET domain & $\begin{array}{l}\text { VARV, ECTV, } \\
\text { CPXV, VACV }\end{array}$ & $\begin{array}{l}\text { Interacts with limited } \\
\text { number of CC and CXC } \\
\text { chemokines through the } \\
\text { receptor binding domain. } \\
\text { Inhibits } \\
\text { chemokine-induced } \\
\text { migration. }\end{array}$ & $\begin{array}{l}\triangle S C P(B 7) V A C V-W R: \text { IN } \\
\text { infection without phenotype } \\
\text { but in ID model was } \\
\text { attenuated (Balb/c mice). } \\
\Delta \text { CrmB-CPXV-BR: Attenuated. } \\
\text { IC infection (Balb/c mice). }\end{array}$ & $\begin{array}{l}\text { CrmD SECRET ECTV: 3ON9 } \\
\text { CrmD SECRET ECTV/CXCL3 (complex): } \\
\text { 3ONA }\end{array}$ & $\begin{array}{l}\text { Alejo et al. (2006), } \\
\text { Palumbo et al. } \\
\text { (1994), Price et al. } \\
\text { (2000) and Xue } \\
\text { et al. (2011) }\end{array}$ \\
\hline \multicolumn{6}{|l|}{ Herpesvirus } \\
\hline $\mathrm{gG}$ & $\begin{array}{l}\text { EHV-1, EHV-3, } \\
\text { BHV-1, BHV-5, } \\
\text { FeHV-1, RanHV } \\
\text { ILTV, PRV, }\end{array}$ & $\begin{array}{l}\text { Bind CC and CXC } \\
\text { chemokines through } \\
\text { receptor binding domain. } \\
\text { EHV-1 gG also prevents } \\
\text { chemokine binding to } \\
\text { GAGs. }\end{array}$ & $\begin{array}{l}\text { ILTV-1: Attenuated in natural } \\
\text { host. } \\
\text { EHV: Exacerbation of } \\
\text { respiratory disease in mice, } \\
\text { exclusively at low doses of } \\
\text { infection. } \\
\text { PRV: No phenotype (pigs). }\end{array}$ & ND & $\begin{array}{l}\text { Bryant et al. (2003), } \\
\text { Costes et al. (2005), } \\
\text { Van de Walle et al. } \\
\text { (2007), } \\
\text { Viejo-Borbolla et al. } \\
\text { (2010a,b) and von } \\
\text { Einem et al. (2007) }\end{array}$ \\
\hline gG1, gG2 & $\begin{array}{l}\mathrm{HSV}-1 \\
\mathrm{HSV}-2\end{array}$ & $\begin{array}{l}\text { Bind CC and CXC } \\
\text { chemokines through the } \\
\text { GAG binding domain, } \\
\text { Enhance chemokine } \\
\text { activity. }\end{array}$ & $\begin{array}{l}\overline{\text { HSV }}-1: \text { Attenuated in ID } \\
\text { infection of mice. } \\
\text { HSV-2: ND }\end{array}$ & ND & $\begin{array}{l}\text { Balan et al. (1994), } \\
\text { Meignier et al. } \\
\text { (1988), } \\
\text { Viejo-Borbolla } \\
\text { et al. (2012) and } \\
\text { Weber et al. (1987) }\end{array}$ \\
\hline M3 & MHV-68 & $\begin{array}{l}\text { Binds } \mathrm{CC}, \mathrm{CXC}, \mathrm{C} \text { and } \mathrm{CX}_{3} \mathrm{C} \\
\text { chemokines. Blocks } \\
\text { through receptor binding } \\
\text { domain and also GAGs } \\
\text { binding domain. }\end{array}$ & $\begin{array}{l}\text { IC injection of C57BL/6 and } \\
\text { CD- } 1 \text { mice: Attenuated. } \\
\text { IN inoculation of C57BL/6 } \\
\text { mice: No phenotype. } \\
\text { IN Infection of wood mice: } \\
\text { Reduced latency and } \\
\text { attenuated. }\end{array}$ & $\begin{array}{l}\text { M3: 1MKF } \\
\text { M3/MCP-1 (complex): 1ML0 } \\
\text { M3/CCL2: (complex): 2NZ1 } \\
\text { M3/CXCL1: (complex): 2NYZ }\end{array}$ & $\begin{array}{l}\text { Alexander et al. } \\
\text { (2002), Hughes } \\
\text { et al. (2011), Parry } \\
\text { et al. (2000) and } \\
\text { van Berkel et al. } \\
\text { (2002) }\end{array}$ \\
\hline pUL21.5 & HCMV & $\begin{array}{l}\text { Blocks CCL5 through the } \\
\text { receptor binding domain. }\end{array}$ & ND & ND & Wang et al. (2004) \\
\hline $\mathrm{R} 17$ & RHVP & $\begin{array}{l}\text { Binds C and CC chemokines } \\
\text { through the receptor } \\
\text { binding domain and } \\
\text { directly binds to cellular } \\
\text { GAGs. }\end{array}$ & ND & ND & $\begin{array}{l}\text { Lubman et al. } \\
(2014)\end{array}$ \\
\hline
\end{tabular}

Routes of infection: IC, intracranial; ID, intradermal; IN, intranasal.

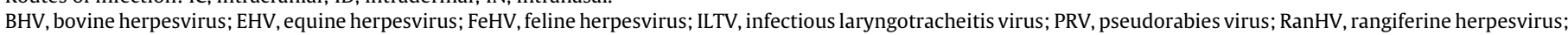
RPXV, rabbit poxvirus.

Deletion of the A41L gene from VACV strain WR enhanced lesion size and altered the inflammatory response to infection in a mouse dermal model (Ng et al., 2001), and the deletion mutant was slightly more virulent than the wild type virus after intranasal infection with low virus doses (Clark et al., 2006). The deletion of the A41L gene from VACV strain modified virus Ankara induces a better protection than wild type virus against a lethal infection with VACV WR (Clark et al., 2006) and a VACV strain modified virus Ankara 
recombinant lacking the $A 41 \mathrm{~L}$ gene together with the $B 16 R$ gene, encoding a secreted interleukin- $1 \beta$ receptor, induces better HIV-1 adaptive and memory responses (Garcia-Arriaza et al., 2010).

\subsection{The M-T7 protein encoded by MYXV}

Initial work identified the MYXV M-T7 gene encoding an abundant 37-kDa glycoprotein that is secreted from infected cells (Upton et al., 1992). This protein has significant sequence similarity to the human and mouse IFN $\gamma$ receptors (IFN $\gamma$-Rs) and was shown to bind to and inhibit the biological activity of rabbit IFN $\gamma$ in a speciesspecific manner (Mossman et al., 1995; Upton et al., 1992).

The M-T7 CKBP was also found to bind a broad range of C, CXC and CC chemokines. A CXCL8 partial C-terminal truncated variant, which displays a markedly lower heparin affinity than does its full-length counterpart, was unable to bind M-T7 (Lalani et al., 1997). Also, they observed that M-T7 is not able to bind to the CXCL8 mutant, which lacks the C-terminal $\alpha$-helix and displays no heparin binding. Heparin competition studies were performed, and they showed that heparin acts as a specific competitor for displacing the binding of chemokine to M-T7. The binding of M-T7 with CXCL8 may be analogous to the interaction between chemokine and heparin (Lalani et al., 1997) (Fig. 1B and Table 1). This finding was unexpected and is a unique property of the IFN $\gamma$-R encoded by MYXV since the IFN $\gamma$-R orthologue encoded by VACV does not bind chemokines (Alcami et al., 1998; Lalani et al., 1997; RuizArguello et al., 2008). The interaction of the M-T7 protein with the chemokine GAG binding domain led to the suggestion that MT7 might prevent the correct localization of chemokines and the formation of a chemokine gradient, rather than the blockade of chemokine binding to specific receptors (Lalani et al., 1997).

Infection of European rabbits with a MYXV mutant in which both copies of the $M-T 7$ gene were disrupted demonstrated that the M$\mathrm{T} 7$ protein plays a significant role in MYXV pathogenesis (Mossman et al., 1996). The recombinant virus was significantly attenuated in rabbits, and decreased viral dissemination and lower viral titers were observed at secondary sites of infection. Also, marked differences were seen in the size and progression of skin lesions, and the onset and severity of secondary bacterial infections. However, these results are difficult to interpret because M-T7 targets IFN- $\gamma$ and chemokines, and both have important roles in inflammatory responses.

MT-7 prevents chronic rejection in rat renal allografts, reduces aortic allograft vasculopathy, delays the influx of macrophages and modulates angiogenesis in the foreign body response (Bedard et al., 2003; Boomker et al., 2005; Liu et al., 2004). Also, recent studies suggest that the anti-inflammatory activity of this protein in rodent models of angioplasty injury as well as aortic and renal transplant is dependent of the ability of M-T7 to block chemokine-GAG interactions (Bartee et al., 2013).

\subsection{A family of poxvirus proteins containing the smallpox virus-encoded chemokine receptor (SECRET) domain}

The study of the VARV-encoded Cytokine response modifier $\mathrm{B}(\mathrm{CrmB})$ led us to the finding of the SECRET domain. CrmB is one of the four tumor necrosis factor receptor (TNFR) homologues encoded by poxviruses, named $\mathrm{CrmB}, \mathrm{CrmC}, \mathrm{CrmD}$ and $\mathrm{CrmE}$. The $\mathrm{N}$-terminal portion of these TNFRs is composed of cysteine-rich domains of the mammalian counterparts that interact with TNF (Hu et al., 1994; Loparev et al., 1998; Saraiva and Alcami, 2001; Smith et al., 1996). The only TNFRs encoded by VARV (CrmB) and ECTV (CrmD), have an additional C-terminal extension for which no sequence similarity to host proteins was found, and it was named SECRET domain. An extensive screening by surface plasmon resonance of all human and mouse chemokines showed that
CrmB interacted with high affinity with a limited set of chemokines (Alejo et al., 2006) (Table 1). The restricted chemokine binding specificity of the SECRET domain differs from the broad binding specificity of the previously identified CKBPs. The analysis of poxviral genomes has identified other gene products encoding SECRET domain-containing proteins (SCPs). The secreted CPXV strain Brighton Red protein V218 and the ECTV strain Naval proteins E12 and E184 were shown to bind chemokines and named SCP-1, 2 and 3, respectively (Alejo et al., 2006).

The ability of VARV CrmB, CPXV CrmB, ECTV CrmD and CPXV SCP-1 to inhibit chemokine-induced migration in vitro has been demonstrated, suggesting that they interrupt the receptor binding site of the chemokine. The fact that all members of the SECRET family bind the same set of chemokines, despite their low sequence similarity, suggests that the SECRET domain has a specific folding to bind chemokines either independently or fused to TNFRs. De novo modeling of VARV CrmB SECRET domain spatial structure revealed structural homology with CPXV 35-kDa and VACV A41 proteins (Antonets et al., 2010). The three dimensional structure of the SECRET domain alone or complexed with a low affinity binding chemokine, CX3CL1, was solved and confirmed that it shares the same $\beta$-sandwich topology with the $35-\mathrm{kDa}$ and $\mathrm{A} 41$ poxvirus CKBPs (Xue et al., 2011) (Fig. 2C).

The identification of the SECRET domain in five different poxvirus proteins is intriguing. This distribution may explain, in part, the variety of genes encoding TNFR homologues in poxvirus genomes, some of which ( $\mathrm{CrmB}$ and $\mathrm{CrmD}$ ) encode this additional chemokine-inhibitory activity. The information on the role of the SECRET domain in viral pathogenesis is limited. Deletion of the SCP $B 7$ gene encoded by VACV strain WR had no major effects on virulence but in a murine intradermal model induced smaller lesions than the control viruses (Price et al., 2000). The CPXV CrmB protein, which blocks both TNF and chemokines in vitro (Alejo et al., 2006), has anti-inflammatory potential in vivo with an approximately 50 -fold increase in $\mathrm{LD}_{50}$ in infected mice (Palumbo et al., 1994). The MYXV M-T2 protein, a secreted TNFR sharing the same domain organization as $\mathrm{CrmB}$ and $\mathrm{CrmD}$, acts as a virulence factor in European rabbits causing a slight reduction of mortality (Upton et al., 1991). However, none of these studies have defined the contribution of the anti-TNF versus anti-chemokine domains present in $\mathrm{CrmB}$ and $\mathrm{CrmD}$ to immune regulation and virulence.

The use of the ECTV CrmD protein as a potential therapeutic revealed that it inhibits the development of ileitis by locally affecting both TNF and chemokine function in the ileum of transgenic mice expressing CrmD in intestinal epithelial cells (Viejo-Borbolla et al., 2010a).

\subsection{The Orf virus (ORFV) CKBP}

ORFV is a parapoxvirus that causes infections in sheep and cattle, and sporadically in humans. ORFV is usually not fatal but can be severe in young animals infected for the first time (Haig and Fleming, 1999). It was shown that ORFV encodes a secreted protein that is most closely related to the ORFV granulocyte macrophagecolony stimulating factor inhibitory protein and also to the $35-\mathrm{kDa}$ CKBP family with only $12-18 \%$ identity. As described for the $35-\mathrm{kDa}$ CKBP, this ORFV protein binds CC chemokines with high affinity but it also interacts with the $C$ chemokine lymphotactin, showing a broader chemokine binding specificity (Seet et al., 2003b) (Table 1). The ORFV CKBP is able to inhibit cellular chemotaxis in vitro (Lateef et al., 2009, 2010) and the interaction with the chemokines is mediated by the GPCR binding domain (Seet et al., 2003b). Dynamic light scattering analysis suggests that the ORFV CKBP is a dimer in solution but the three dimensional structure has not yet been solved (Counago et al., 2010). 
It has been demonstrated that the ORFV CKBP is a potent inhibitor of inflammatory monocyte recruitment in a mouse skin model (Lateef et al., 2009), and inhibits the recruitment of dendritic cells to sites of skin inflammation, their migration to peripheral lymph nodes and the $\mathrm{T}$ responsiveness in the inguinal lymph nodes (Lateef et al., 2010).

\section{Herpesvirus}

\subsection{The M3 protein encoded by murine gammaherpesvirus 68 (MHV-68)}

M3 was identified as a broad spectrum CKBP, which is abundantly secreted during acute infection of MHV-68 (Parry et al., 2000; van Berkel et al., 2000), a pathogen of wild rodents. M3 is able to bind promiscuously, but with high affinities, to human and murine chemokines belonging to all chemokine classes (Table 1).

A dual anti-chemokine function for M3 has been proposed. On the one hand, and similar to the poxvirus 35-kDa protein, it is able to bind free chemokines with high affinity and to block chemokine-receptor interactions by competitive inhibition. On the other hand, although M3 is unable to bind GAGs directly it inhibits the interaction of chemokines with GAGs affecting the chemotactic gradients necessary for directed cell migration (Webb et al., 2004). Moreover, M3 has been shown to disrupt preformed chemokineGAGs in vitro.

Structural studies of M3-chemokine complexes have revealed the structural basis for this dual anti-chemokine function (Alexander et al., 2002; Alexander-Brett and Fremont, 2007; Webb et al., 2003). Crystallographic structures of M3 complexed with CCL2 or XCL1 have revealed that the M3 C-terminal domain engages with those conserved residues from diverse chemokine subclasses involved in receptor binding with the same overall binding geometry (Alexander et al., 2002; Webb et al., 2003). Indeed, the promiscuous chemokine binding by $\mathrm{M} 3$ could be facilitated by the flexibility of contact loops and certain domains of the M3 dimer that mimic the CCL2-interacting structure of its receptor CCR2 (Alexander et al., 2002). However, the M3 ability of blocking the chemokine-GAG interaction relies on its acidic N-terminal domain which exhibits electrostatic complementarity allowing engagement with chemokine basics clusters involved in GAG association. Interestingly, the N-terminal domain of M3 has structural similarities to the poxvirus SECRET domain and the 35-kDa and A41 CKBPs (Fig. 2B and C).

After intranasal infection, MHV-68 replicates transiently in respiratory epithelial cells and spreads to lymphoid tissue where latency is established in B lymphocytes, macrophages and dendritic cells. In vivo studies using M3 deletion mutants of MHV-68 have provided contradictory results and highlighted the relevance of the animal model used in these studies. An initial report showed that targeted disruption of the $M 3$ gene had surprisingly little effect on lytic virus replication in the respiratory tract or the initial spread of virus to lymphoid tissues after intranasal inoculation (Bridgeman et al., 2001) in C57BL/6 mice. However, the mutant virus failed to establish normal levels of latency in splenic B cells. Interestingly, in vivo $\mathrm{CD}^{+} \mathrm{T}$ cell depletion largely reversed the phenotype, suggesting that chemokine neutralization by M3 may function to block $\mathrm{CD} 8^{+} \mathrm{T}$ cell recruitment into lymphoid tissue and to enable the establishment of MHV-68 latency. A second report assigned an attenuated phenotype to the M3 deletion mutant in an intracranial model of infection using CD-1 and C57BL/6 mice, but not in the intranasal model (van Berkel et al., 2002). Recently, a study using wood mice (the natural host of MHV-68) showed that the lack of M3 significantly reduced the ability of MHV-68 to establish latency in lung and spleen (Hughes et al., 2011).

\subsection{The glycoprotein $G(g G)$ encoded by alphaherpesviruses}

gG from alphaherpesviruses is a component of the viral particle which is expressed as a membrane-anchored glycoprotein at the plasma membrane of infected cells. After proteolytic cleavage of this membrane form, an additional secreted version of gG (SgG) is released into the medium of infected cells. To date, chemokine binding activity has been identified in the supernatants from diverse cells infected with animal alphaherpesvirus such as equine herpesvirus 1 and 3, bovine herpesvirus 1 and 5, felid herpesvirus 1 or pseudorabies virus (Bryant et al., 2003; Costes et al., 2005; Van de Walle et al., 2007; Viejo-Borbolla et al., 2010b). The amino acid residues involved in $\mathrm{gG}$ interaction with chemokines have been identified by mutagenesis of equine herpesvirus $1 \mathrm{gG}$ and expression of hybrid molecules with equine herpesvirus $4 \mathrm{gG}$, an orthologue that does not bind chemokines (Van de Walle et al., 2009) (Table 1).

Although initial studies did not find chemokine binding activity in supernatants from cells infected with human alphaherpesviruses, a recent report identified this activity in supernatants from HSV-2-infected cultures (Viejo-Borbolla et al., 2012). However chemokine-binding activity has not been detected in supernatants from cells infected with HSV-1 or varicella zoster virus. With HSV-1 this is explained by gG not being secreted, and chemokine binding activity has been detected in the plasma membrane of cells infected with wild type HSV-1 but not with a gG-deficient HSV-1 mutant indicating that the membrane-anchored form also retains chemokine binding activity (Viejo-Borbolla et al., 2012). In the case of varicella zoster virus, the gene encoding gG is not present in the viral genome (Gomi et al., 2002).

The interaction of recombinant SgGs from HSV-1 and HSV-2 with a variety of CC and CXC chemokines occurs with high affinity through the GAG-binding domain in the chemokine (Viejo-Borbolla et al., 2012). The mechanism of action of SgGs from HSV is unique among vCKBPs. Like almost all CKBPs, gG homologues encoded by other animal alphaherpesviruses, bind a variety of chemokines to interfere with chemokine interaction with cellular receptors or impairing chemokine presentation to GAGs, resulting in the inhibition of cellular chemotaxis (Costes et al., 2005; Van de Walle et al., 2007; Viejo-Borbolla et al., 2010b). On the contrary, the interaction of SgGs from HSV-1 and HSV-2 with chemokines has the opposite effect, the enhancement of chemokine function. Thus, the addition of SgG has been recently shown to increase the in vitro CXCL12 $\beta$ induced cell migration and more importantly SgG from HSV-2 has been shown in vivo to increase the CCL28-mediated chemotaxis of leukocytes in a mouse air pouch model (Viejo-Borbolla et al., 2012).

Interestingly, felid herpesvirus $1 \mathrm{gG}$ present at the surface of the virion has also been demonstrated to bind chemokines (Costes et al., $2005,2006)$ raising the possibility that the incoming virion could interfere with chemokine function. In the case of HSV, it should be interesting to know whether gG incorporated into the virion envelope enhances chemokine function as reported for recombinant SgG.

Recombinant HSV-1 viruses lacking gG expression have been tested in vivo in three different studies (Balan et al., 1994; Meignier et al., 1988; Weber et al., 1987). In all cases, different degrees of attenuation were observed, suggesting the contribution of gG to HSV-1 pathogenesis. This attenuated phenotype might be explained by the enhancement of chemokine function recently reported for HSV-1 gG. The role of HSV-2 gG on pathogenesis remains unclear since no gG deletion mutants have been reported to date. Deletion of the gG gene from pseudorabies virus did not affect virulence or immunogenicity in pigs (Kimman et al., 1992; Thomsen et al., 1987). In the case of infectious laryngotracheitis virus, an alphaherpesvirus that causes acute respiratory disease in poultry, gG was shown to bind with high affinity murine CC and 
CXC chemokines and to inhibit leukocyte chemotaxis (Devlin et al., 2010). The corresponding gG-deletion mutant exhibits an attenuated phenotype in its natural host compared to wild-type virus, and it is an effective attenuated vaccine since it induces protection against disease following challenge with virulent virus (Devlin et al., 2007).

Equine herpesvirus $1 \mathrm{gG}$ has been shown to bind a broad range of chemokines and to inhibit equine CXCL8 induced migration of neutrophils. As described for the MHV-68 M3 protein, it also prevents the interaction of chemokines with GAGs (Bryant et al., 2003; Van de Walle et al., 2007). The effect of equine hespervirus $1 \mathrm{gG}$ deletion on virus pathogenesis has been tested in mouse models of respiratory infection. However, depending on the mouse strain and dose of virus used, the results obtained were different and a clear phenotype could not be assigned to this mutant (Van de Walle et al., 2007; von Einem et al., 2007).

\subsection{The human cytomegalovirus pUL21.5 protein}

Human cytomegalovirus encodes a small secreted glycoprotein which has been demonstrated to bind CCL5 with high affinity and to block the interaction of human CCL5 with specific cellular receptors (Wang et al., 2004) (Table 1). In contrast to other virus-encoded CKBPs, pUL21.5 appears to have an exquisite specificity for the CCL5, but due to the limited number of cytokines tested in this study the possibility that pUL21.5 could bind additional chemokines cannot be ruled out. Although the exact role of this protein during infection is not known, the mRNA encoding pUL21.5 is incorporated into virions, suggesting that this CKBP could be expressed to modulate the host response even before the transcriptional activation of the infecting viral genome (Wang et al., 2004).

\section{4. $R 17$, a potential CKBP from the recently characterized rodent herpesvirus Peru}

Rodent herpesvirus Peru is a recently characterized rhadinovirus related to MHV-68 and Kaposi's sarcoma-associated herpesvirus that establishes acute and latent infection in the laboratory (Loh et al., 2011). Recently, R17 was identified, among the secreted proteins encoded uniquely by rodent herpesvirus Peru, as a CKBP. R17 binds members of 2 of 4 chemokine families (CC and C) with high affinities blocking their ability to trigger cell signaling through chemokine receptors (Lubman et al., 2014). In addition to chemokine binding, and unlike M3 from MHV-68, R17 can directly bind to cell surface GAGs through two BBXB motifs that are commonly found in GAG binding proteins (Table 1). Therefore, R17 binding to chemokines and GAGs can occur simultaneously in two different sites and could enhance the association of chemokines with cell surfaces (Lubman et al., 2014).

\section{The immune modulatory functions of virus-encoded secreted CKBPs}

The production of secreted versions of cytokine receptors that bind cytokines with high affinity and block their activity is a strategy employed by the immune system of humans and mammals to control the immune response and prevent pathological consequences that may be caused by an uncontrolled immune response. Large DNA viruses, such as poxviruses and herpesviruses, have acquired a similar strategy to control the host anti-viral immunity, and they have incorporated into their genomes genes encoding soluble versions of host cytokine receptors to be used as potent inhibitors of cytokine activity (Alcami, 2003). Examples of virus-encoded homologues of host proteins include the secreted version of receptors for TNF, IL-1 $\beta$ or IFN- $\gamma$. Due to the structural nature of the seven-transmembrane-domain the production of secreted versions of these receptors is not feasible and alternative mechanisms have evolved to limit chemokine activity. The host immune system uses membrane-anchored decoy receptors, such as the atypical chemokine receptors ACKR1, ACKR2 or ACKR4, that bind chemokines but do not transduce signals and function as chemokine scavengers (Graham and McKimmie, 2006; Mantovani et al., 2006). In contrast, viruses encode secreted proteins of unique structure not found in host proteins that bind chemokines with high affinity and block their biological activity (Alcami, 2003; Seet et al., 2003a).

CKBPs have been found to be produced by non-viral pathogens. A CKBP secreted by Schistosoma mansoni, a trematode parasite that infects humans causing schistisomiasis, was identified (Smith et al., 2005). This protein is expressed only in schistosome egg secretions but not in the other life cycle stages (cercariae, schistosomular, worms) of S. mansoni and interacts with several chemokines, including CCL2, CCL3, CCL5, CXCL8 and CX3CL1, preventing their interaction with cellular receptors. Secretion of $S$. mansoni CKBP by live eggs modulates the differential recruitment of cells and the size of the egg granuloma (Smith et al., 2005), suggesting that smCKBP may facilitate granuloma formation and the propagation of the $S$. mansoni eggs. The evasins encoded by ticks represent a second example of non-viral CKBPs (Deruaz et al., 2008; Frauenschuh et al., 2007). The evasin family comprises three members and are small proteins of 7-12 kDa produced by the salivary glands. It has been suggested that evasins may help to modulate chemokinemediated responses and inflammation when the ticks feed blood from their host for several days. Evasin-1 and Evasin-3 show restricted chemokine binding specificity, whereas Evasin- 4 binds most CC chemokines. Evasins block the binding of chemokines to their receptor and inhibit chemokine activity. The crystal structure of evasins reveals novel protein folds (Deruaz et al., 2008; Dias et al., 2009). A recent report describes the first human secreted protein that inhibits chemokine activity (Dyer et al., 2014) and is unrelated to GPCRs. TNF-stimulated gene/protein- 6 is secreted and inhibits neutrophil transendothelial migration, and was known to interact with several proteins (inter-alpha-inhibitor and thrombospondin1) and GAGs. TNF-stimulated gene/protein- 6 was found to interact with CXCL8, to antagonize the CXCL8-heparin interaction and to impair the transport of CXCL8 across the endothelial cell monolayer, which could account for its anti-inflammatory effect.

The main function of CKBPs is to inhibit chemokine activity and the subsequent activation and migration of leukocytes. Most of the CKBPs inhibit chemokine interaction with their cognate receptors by blocking the receptor binding site in the chemokine. The finding that some CKBPs interact with the GAG binding site in the chemokine and presumably prevent the interaction of chemokines with GAGs and the formation of a chemokine gradient in tissues supports the notion that targetting the chemokine-GAG interaction is an efficient strategy to modulate chemokine activity in vivo (Proudfoot, 2006). The diverse binding specificity of CKBPs, from those highly selective for a few chemokines (e.g. evasins, SECRET domain) to those with broad binding specificity (e.g. poxvirus 35$\mathrm{kDa}$ protein, herpesvirus M3) suggests that CKBPs target a specific set of chemokines involved in defence mechanisms that are relevant against particular pathogens. Thus a specific CKBP may be optimized to modulate specific arms of the immune response and be efficient to control subsets of leukocytes in particular tissues. The finding that gG from HSV-1 and HSV-2 enhance chemokine activity, rather than inhibit chemokine activity, like the gG orthologues from animal herpesviruses, illustrate that CKBPs have adapted to the requirements of specific viruses. In this case, HSV-1 and HSV2 may benefit from the potentiation of chemokine activity that recruits immune cells to sites of infection.

Although a considerable amount of work has been done to characterize the biological properties of virus-encoded CKBPs, future 
research should characterize further the ability of CKBPs to modulate immune responses in models of infection and inflammation.

\section{Acknowledgments}

The work in the author's laboratory was funded by the Spanish Ministry of Economy and Competitiviness (grants SAF2009-07857 and SAF2012-38957).H.H. was recipient of a Formacion de Personal Investigador Ph.D. Studentship and B.H. was supported by a JAE postdoctoral fellowship from Consejo Superior de Investigaciones Científicas.

\section{References}

Alcami, A., 2003. Viral mimicry of cytokines, chemokines and their receptors. Nat. Rev. Immunol. 3 (1), 36-50.

Alcami, A., Koszinowski, U.H., 2000. Viral mechanisms of immune evasion. Immunol. Today 21 (9), 447-455.

Alcami, A., Symons, J.A., Collins, P.D., Williams, T.J., Smith, G.L., 1998. Blockade of chemokine activity by a soluble chemokine binding protein from vaccinia virus. J. Immunol. 160 (2), 624-633.

Alejo, A., Ruiz-Arguello, M.B., Ho, Y., Smith, V.P., Saraiva, M., Alcami, A., 2006. A chemokine-binding domain in the tumor necrosis factor receptor from variola (smallpox) virus. Proc. Natl. Acad. Sci. U.S.A. 103 (15), 5995-6000.

Alexander, J.M., Nelson, C.A., van Berkel, V., Lau, E.K., Studts, J.M., Brett, T.J., Speck, S.H., Handel, T.M., Virgin, H.W., Fremont, D.H., 2002. Structural basis of chemokine sequestration by a herpesvirus decoy receptor. Cell 111 (3), 343-356.

Alexander-Brett, J.M., Fremont, D.H., 2007. Dual GPCR and GAG mimicry by the M3 chemokine decoy receptor. J. Exp. Med. 204 (13), 3157-3172.

Antonets, D.V., Nepomnyashchikh, T.S., Shchelkunov, S.N., 2010. SECRET domain of variola virus CrmB protein can be a member of poxviral type II chemokinebinding proteins family. BMC Res. Notes 3, 271.

Arnold, P.L., Fremont, D.H., 2006. Structural determinants of chemokine binding by an Ectromelia virus-encoded decoy receptor. J. Virol. 80 (15), 7439-7449.

Baggiolini, M., 1998. Chemokines and leukocyte traffic. Nature 392 (6676), 565-568.

Bahar, M.W., Kenyon, J.C., Putz, M.M., Abrescia, N.G., Pease, J.E., Wise, E.L., Stuart, D.I., Smith, G.L., Grimes, J.M., 2008. Structure and function of A41, a vaccinia virus chemokine binding protein. PLoS Pathog. 4 (1), e5.

Balan, P., Davis-Poynter, N., Bell, S., Atkinson, H., Browne, H., Minson, T., 1994. An analysis of the in vitro and in vivo phenotypes of mutants of herpes simplex virus type 1 lacking glycoproteins gG, gE, gI or the putative gJ. J. Gen. Virol. 75 (Pt 6), 1245-1258.

Bartee, M.Y., Chen, H., Dai, E., Liu, L.Y., Davids, J.A., Lucas, A., 2013. Defining the antiinflammatory activity of a potent myxomaviral chemokine modulating protein, M-T7, through site directed mutagenesis. Cytokine 65 (1), 79-87.

Beck, C.G., Studer, C., Zuber, J.F., Demange, B.J., Manning, U., Urfer, R., 2001. The viral CC chemokine-binding protein vCCI inhibits monocyte chemoattractant protein-1 activity by masking its CCR2B-binding site. J. Biol. Chem. 276 (46), 43270-43276.

Bedard, E.L., Kim, P., Jiang, J., Parry, N., Liu, L., Wang, H., Garcia, B., Li, X., McFadden, G., Lucas, A., Zhong, R., 2003. Chemokine-binding viral protein M-T7 prevents chronic rejection in rat renal allografts. Transplantation 76 (1), 249-252.

Biron, C.A., 2001. Interferons alpha and beta as immune regulators - a new look. Immunity 14 (6), 661-664.

Blanpain, C., Doranz, B.J., Bondue, A., Govaerts, C., De Leener, A., Vassart, G., Doms, R.W., Proudfoot, A., Parmentier, M., 2003. The core domain of chemokines binds CCR5 extracellular domains while their amino terminus interacts with the transmembrane helix bundle. J. Biol. Chem. 278 (7), 5179-5187.

Boomker, J.M., Luttikhuizen, D.T., Veninga, H., de Leij, L.F., The, T.H., de Haan, A., van Luyn, M.J., Harmsen, M.C., 2005. The modulation of angiogenesis in the foreign body response by the poxviral protein M-T7. Biomaterials 26 (23), 4874-4881.

Bridgeman, A., Stevenson, P.G., Simas, J.P., Efstathiou, S., 2001. A secreted chemokine binding protein encoded by murine gammaherpesvirus-68 is necessary for the establishment of a normal latent load. J. Exp. Med. 194 (3), 301-312.

Bryant, N.A., Davis-Poynter, N., Vanderplasschen, A., Alcami, A., 2003. Glycoprotein G isoforms from some alphaherpesviruses function as broad-spectrum chemokine binding proteins. EMBO J. 22 (4), 833-846.

Buatois, V., Fagete, S., Magistrelli, G., Chatel, L., Fischer, N., Kosco-Vilbois, M.H., Ferlin, W.G., 2010. Pan-CC chemokine neutralization restricts splenocyte egress and reduces inflammation in a model of arthritis. J. Immunol. 185 (4), 2544-2554.

Burns, J.M., Dairaghi, D.J., Deitz, M., Tsang, M., Schall, T.J., 2002. Comprehensive mapping of poxvirus vCCI chemokine-binding protein. Expanded range of ligand interactions and unusual dissociation kinetics. J. Biol. Chem. 277 (4), 2785-2789.

Bursill, C.A., McNeill, E., Wang, L., Hibbitt, O.C., Wade-Martins, R., Paterson, D.J., Greaves, D.R., Channon, K.M., 2009. Lentiviral gene transfer to reduce atherosclerosis progression by long-term CC-chemokine inhibition. Gene Ther. 16 (1), 93-102.

Carfi, A., Smith, C.A., Smolak, P.J., McGrew, J., Wiley, D.C., 1999. Structure of a soluble secreted chemokine inhibitor vCCI (p35) from cowpox virus. Proc. Natl. Acad. Sci. U.S.A. 96 (22), 12379-12383.
Clark, R.H., Kenyon, J.C., Bartlett, N.W., Tscharke, D.C., Smith, G.L., 2006. Deletion of gene A41L enhances vaccinia virus immunogenicity and vaccine efficacy. J. Gen. Virol. 87 (Pt 1), 29-38.

Costes, B., Ruiz-Arguello, M.B., Bryant, N.A., Alcami, A., Vanderplasschen, A., 2005 Both soluble and membrane-anchored forms of felid herpesvirus 1 glycoprotein $\mathrm{G}$ function as a broad-spectrum chemokine-binding protein. J. Gen. Virol. 86 (Pt 12), 3209-3214.

Costes, B., Thirion, M., Dewals, B., Mast, J., Ackermann, M., Markine-Goriaynoff, N., Gillet, L., Vanderplasschen, A., 2006. Felid herpesvirus 1 glycoprotein G is a structural protein that mediates the binding of chemokines on the viral envelope. Microbes Infect. 8 (11), 2657-2667.

Counago, R.M., Fleming, S.B., Mercer, A.A., Krause, K.L., 2010. Crystallization and preliminary X-ray analysis of the chemokine-binding protein from orf virus (Poxviridae). Acta Crystallogr. Sect. F Struct. Biol. Cryst. Commun. 66 (Pt 7), 819-823.

Dealwis, C., Fernandez, E.J., Thompson, D.A., Simon, R.J., Siani, M.A., Lolis, E., 1998. Crystal structure of chemically synthesized [N33A] stromal cell-derived factor 1alpha, a potent ligand for the HIV-1 "fusin" coreceptor. Proc. Natl. Acad. Sci. U.S.A. 95 (12), 6941-6946.

Deruaz, M., Frauenschuh, A., Alessandri, A.L., Dias, J.M., Coelho, F.M., Russo R.C., Ferreira, B.R., Graham, G.J., Shaw, J.P., Wells, T.N., Teixeira, M.M., Power, C.A., Proudfoot, A.E., 2008. Ticks produce highly selective chemokine binding proteins with antiinflammatory activity. J. Exp. Med. 205 (9), 2019-2031.

Devlin, J.M., Browning, G.F., Hartley, C.A., Gilkerson, J.R., 2007. Glycoprotein C deficient infectious laryngotracheitis virus is a candidate attenuated vaccine. Vaccine 25 (18), 3561-3566.

Devlin, J.M., Viejo-Borbolla, A., Browning, G.F., Noormohammadi, A.H., Gilkerson, J.R., Alcami, A., Hartley, C.A., 2010. Evaluation of immunological responses to a glycoprotein $G$ deficient candidate vaccine strain of infectious laryngotracheitis virus. Vaccine 28 (5), 1325-1332.

Dias, J.M., Losberger, C., Deruaz, M., Power, C.A., Proudfoot, A.E., Shaw, J.P., 2009 Structural basis of chemokine sequestration by a tick chemokine binding protein: the crystal structure of the complex between Evasin-1 and CCL3. PLoS ONE 4 (12), e8514.

Dyer, D.P., Thomson, J.M., Hermant, A., Jowitt, T.A., Handel, T.M., Proudfoot, A.E., Day A.J., Milner, C.M., 2014. TSG-6 inhibits neutrophil migration via direct interaction with the chemokine CXCL8. J. Immunol. 192 (5), 2177-2185.

Fernandez, E.J., Lolis, E., 2002. Structure, function, and inhibition of chemokines Annu. Rev. Pharmacol. Toxicol. 42, 469-499.

Finlay, B.B., McFadden, G., 2006. Anti-immunology: evasion of the host immune system by bacterial and viral pathogens. Cell 124 (4), 767-782.

Frauenschuh, A., Power, C.A., Deruaz, M., Ferreira, B.R., Silva, J.S., Teixeira, M.M. Dias, J.M., Martin, T., Wells, T.N., Proudfoot, A.E., 2007. Molecular cloning and characterization of a highly selective chemokine-binding protein from the tick Rhipicephalus sanguineus. J. Biol. Chem. 282 (37), 27250-27258.

Garcia-Arriaza, J., Najera, J.L., Gomez, C.E., Sorzano, C.O., Esteban, M., 2010. Immunogenic profiling in mice of a HIV/AIDS vaccine candidate (MVA-B) expressing four HIV-1 antigens and potentiation by specific gene deletions. PLoS ONE 5 (8), e12395.

Gomi, Y., Sunamachi, H., Mori, Y., Nagaike, K., Takahashi, M., Yamanishi, K., 2002. Comparison of the complete DNA sequences of the Oka varicella vaccine and its parental virus. J. Virol. 76 (22), 11447-11459.

Graham, G.J., McKimmie, C.S., 2006. Chemokine scavenging by D6: a movable feast? Trends Immunol. 27 (8), 381-386.

Graham, K.A., Lalani, A.S., Macen, J.L., Ness, T.L., Barry, M., Liu, L.Y., Lucas, A., ClarkLewis, I., Moyer, R.W., McFadden, G., 1997. The T1/35kDa family of poxvirussecreted proteins bind chemokines and modulate leukocyte influx into virusinfected tissues. Virology 229 (1), 12-24.

Guidotti, L.G., Chisari, F.V., 2000. Cytokine-mediated control of viral infections. Virology 273 (2), 221-227.

Haig, D.M., Fleming, S., 1999. Immunomodulation by virulence proteins of the parapoxvirus orf virus. Vet. Immunol. Immunopathol. 72 (1-2), 81-86.

Handel, T.M., Johnson, Z., Crown, S.E., Lau, E.K., Proudfoot, A.E., 2005. Regulation of protein function by glycosaminoglycans - as exemplified by chemokines. Annu. Rev. Biochem. 74, 385-410.

Hu, F.Q., Smith, C.A., Pickup, D.J., 1994. Cowpox virus contains two copies of an early gene encoding a soluble secreted form of the type II TNF receptor. Virology 204 (1), 343-356.

Hughes, D.J., Kipar, A., Leeming, G.H., Bennett, E., Howarth, D., Cummerson, J.A., Papoula-Pereira, R., Flanagan, B.F., Sample, J.T., Stewart, J.P., 2011. Chemokine binding protein M3 of murine gammaherpesvirus 68 modulates the host response to infection in a natural host. PLoS Pathog. 7 (3), e1001321.

Johnson, Z., Proudfoot, A.E., Handel, T.M., 2005. Interaction of chemokines and glycosaminoglycans: a new twist in the regulation of chemokine function with opportunities for therapeutic intervention. Cytokine Growth Factor Rev. 16 (6), $625-636$.

Kimman, T.G., Pol, J.M., de Wind, N., Oei-Lie, N., Berns, A.J., Gielkens, A.L., 1992. Role of different genes in the virulence and pathogenesis of Aujeszky's disease virus. Vet. Microbiol. 33 (1-4), 45-52.

Kuo, N.W., Gao, Y.G., Schill, M.S., Isern, N., Dupureur, C.M., Liwang, P.J., 2014. Structural insights into the interaction between a potent anti-inflammatory protein viral CC chemokine inhibitor (vCCI), and the human CC chemokine, Eotaxin-1. J Biol. Chem. 289 (10), 6592-6603.

Lalani, A.S., Graham, K., Mossman, K., Rajarathnam, K., Clark-Lewis, I., Kelvin, D. McFadden, G., 1997. The purified myxoma virus gamma interferon receptor 
homolog M-T7 interacts with the heparin-binding domains of chemokines. J. Virol. 71 (6), 4356-4363.

Lalani, A.S., Masters, J., Graham, K., Liu, L., Lucas, A., McFadden, G., 1999. Role of the myxoma virus soluble CC-chemokine inhibitor glycoprotein, M-T1, during myxoma virus pathogenesis. Virology 256 (2), 233-245.

Lalani, A.S., Ness, T.L., Singh, R., Harrison, J.K., Seet, B.T., Kelvin, D.J., McFadden, G., Moyer, R.W., 1998. Functional comparisons among members of the poxvirus T1/35kDa family of soluble CC-chemokine inhibitor glycoproteins. Virology 250 (1), 173-184

Lateef, Z., Baird, M.A., Wise, L.M., Mercer, A.A., Fleming, S.B., 2009. Orf virus-encoded chemokine-binding protein is a potent inhibitor of inflammatory monocyte recruitment in a mouse skin model. J. Gen. Virol. 90 (Pt 6), 1477-1482.

Lateef, Z., Baird, M.A., Wise, L.M., Young, S., Mercer, A.A., Fleming, S.B., 2010. The chemokine-binding protein encoded by the poxvirus orf virus inhibits recruitment of dendritic cells to sites of skin inflammation and migration to peripheral lymph nodes. Cell. Microbiol. 12 (5), 665-676.

Liu, L., Dai, E., Miller, L., Seet, B., Lalani, A., Macauley, C., Li, X., Virgin, H.W., Bunce, C., Turner, P., Moyer, R., McFadden, G., Lucas, A., 2004. Viral chemokine-binding proteins inhibit inflammatory responses and aortic allograft transplant vasculopathy in rat models. Transplantation 77 (11), 1652-1660.

Loh, J., Zhao, G., Nelson, C.A., Coder, P., Droit, L., Handley, S.A., Johnson, L.S., Vachharajani, P., Guzman, H., Tesh, R.B., Wang, D., Fremont, D.H., Virgin, H.W., 2011. Identification and sequencing of a novel rodent gammaherpesvirus that establishes acute and latent infection in laboratory mice. J. Virol. 85 (6), 2642-2656.

Loparev, V.N., Parsons, J.M., Knight, J.C., Panus, J.F., Ray, C.A., Buller, R.M., Pickup, D.J., Esposito, J.J., 1998. A third distinct tumor necrosis factor receptor of orthopoxviruses. Proc. Natl. Acad. Sci. U.S.A. 95 (7), 3786-3791.

Lubman, O.Y., Cella, M., Wang, X., Monte, K., Lenschow, D.J., Huang, Y.H., Fremont, D.H., 2014. Rodent herpesvirus Peru encodes a secreted chemokine decoy receptor. J. Virol. 88 (1), 538-546.

Mantovani, A., Bonecchi, R., Locati, M., 2006. Tuning inflammation and immunity by chemokine sequestration: decoys and more Nat Rev Immunol.6(12),907-918.

Martinez-Pomares, L., Thompson, J.P., Moyer, R.W., 1995. Mapping and investigation of the role in pathogenesis of the major unique secreted 35-kDa protein of rabbitpox virus. Virology 206 (1), 591-600.

Meignier, B., Longnecker, R., Mavromara-Nazos, P., Sears, A.E., Roizman, B., 1988. Virulence of and establishment of latency by genetically engineered deletion mutants of herpes simplex virus 1 . Virology 162 (1), 251-254.

Mossman, K., Nation, P., Macen, J., Garbutt, M., Lucas, A., McFadden, G., 1996. Myxoma virus M-T7, a secreted homolog of the interferon-gamma receptor, is a critical virulence factor for the development of myxomatosis in European rabbits. Virology 215 (1), 17-30.

Mossman, K., Upton, C., McFadden, G., 1995. The myxoma virus-soluble interferongamma receptor homolog, M-T7, inhibits interferon-gamma in a species-specific manner. J. Biol. Chem. 270 (7), 3031-3038.

Ng, A., Tscharke, D.C., Reading, P.C., Smith, G.L., 2001. The vaccinia virus A41L protein is a soluble $30 \mathrm{kDa}$ glycoprotein that affects virus virulence. J. Gen. Virol. 82 (Pt 9), 2095-2105

Palumbo, G.J., Buller, R.M., Glasgow, W.C., 1994. Multigenic evasion of inflammation by poxviruses. J. Virol. 68 (3), 1737-1749.

Parry, C.M., Simas, J.P., Smith, V.P., Stewart, C.A., Minson, A.C., Efstathiou, S., Alcami, A., 2000. A broad spectrum secreted chemokine binding protein encoded by a herpesvirus. J. Exp. Med, 191 (3), 573-578.

Price, N., Tscharke, D.C., Hollinshead, M., Smith, G.L., 2000. Vaccinia virus gene B7R encodes an $18-\mathrm{kDa}$ protein that is resident in the endoplasmic reticulum and affects virus virulence. Virology 267 (1), 65-79.

Proudfoot, A.E., 2002. Chemokine receptors: multifaceted therapeutic targets. Nat. Rev. Immunol. 2 (2), 106-115.

Proudfoot, A.E., 2006. The biological relevance of chemokine-proteoglycan interactions. Biochem. Soc. Trans. 34 (Pt 3), 422-426.

Reading, P.C., Symons, J.A., Smith, G.L., 2003. A soluble chemokine-binding protein from vaccinia virus reduces virus virulence and the inflammatory response to infection. J. Immunol. 170 (3), 1435-1442.

Ruiz-Arguello, M.B., Smith, V.P., Campanella, G.S., Baleux, F., Arenzana-Seisdedos, F., Luster, A.D., Alcami, A., 2008. An ectromelia virus protein that interacts with chemokines through their glycosaminoglycan binding domain. J. Virol. 82 (2), 917-926.

Saraiva, M., Alcami, A., 2001. CrmE, a novel soluble tumor necrosis factor receptor encoded by poxviruses. J. Virol. 75 (1), 226-233.

Seet, B.T., Johnston, J.B., Brunetti, C.R., Barrett, J.W., Everett, H., Cameron, C., Sypula, J., Nazarian, S.H., Lucas, A., McFadden, G., 2003a. Poxviruses and immune evasion. Annu. Rev. Immunol. 21, 377-423.

Seet, B.T., McCaughan, C.A., Handel, T.M., Mercer, A., Brunetti, C., McFadden, G., Fleming, S.B., 2003b. Analysis of an orf virus chemokine-binding protein: Shifting ligand specificities among a family of poxvirus viroceptors. Proc. Natl. Acad. Sci. U.S.A. 100 (25), 15137-15142.

Seet, B.T., Singh, R., Paavola, C., Lau, E.K., Handel, T.M., McFadden, G., 2001. Molecular determinants for CC-chemokine recognition by a poxvirus CC-chemokine inhibitor. Proc. Natl. Acad. Sci. U.S.A. 98 (16), 9008-9013.
Smith, C.A., Hu, F.Q., Smith, T.D., Richards, C.L., Smolak, P., Goodwin, R.G., Pickup, D.J., 1996. Cowpox virus genome encodes a second soluble homologue of cellular TNF receptors, distinct from CrmB, that binds TNF but not LT alpha. Virology 223 (1), 132-147.

Smith, C.A., Smith, T.D., Smolak, P.J., Friend, D., Hagen, H., Gerhart, M., Park, L., Pickup, D.J., Torrance, D., Mohler, K., Schooley, K., Goodwin, R.G., 1997. Poxvirus genomes encode a secreted, soluble protein that preferentially inhibits beta chemokine activity yet lacks sequence homology to known chemokine receptors. Virology 236 (2), 316-327.

Smith, G.L., McFadden, G., 2002. Smallpox: anything to declare? Nat. Rev. Immunol. 2(7) , 521-527.

Smith, P., Fallon, R.E., Mangan, N.E., Walsh, C.M., Saraiva, M., Sayers, J.R., McKenzie, A.N., Alcami, A., Fallon, P.G., 2005. Schistosoma mansoni secretes a chemokine binding protein with antiinflammatory activity. J. Exp. Med. 202 (10), 1319-1325.

Thomsen, D.R., Marchioli, C.C., Yancey Jr., R.J., Post, L.E., 1987. Replication and virulence of pseudorabies virus mutants lacking glycoprotein gX. J. Virol. 61 (1), 229-232.

Upton, C., Macen, J.L., Schreiber, M., McFadden, G., 1991. Myxoma virus expresses a secreted protein with homology to the tumor necrosis factor receptor gene family that contributes to viral virulence. Virology 184 (1), 370-382.

Upton, C., Mossman, K., McFadden, G., 1992. Encoding of a homolog of the IFNgamma receptor by myxoma virus. Science 258 (5086), 1369-1372.

van Berkel, V., Barrett, J., Tiffany, H.L., Fremont, D.H., Murphy, P.M., McFadden, G. Speck, S.H., Virgin, H.I., 2000. Identification of a gammaherpesvirus selective chemokine binding protein that inhibits chemokine action. J. Virol. 74 (15), 6741-6747.

van Berkel, V., Levine, B., Kapadia, S.B., Goldman, J.E., Speck, S.H., Virgin, H.W., 2002. Critical role for a high-affinity chemokine-binding protein in gammaherpesvirus-induced lethal meningitis. J. Clin. Invest. 109 (7), 905-914.

Van de Walle, G.R., Kaufer, B.B., Chbab, N., Osterrieder, N., 2009. Analysis of the herpesvirus chemokine-binding glycoprotein $\mathrm{G}$ residues essential for chemokine binding and biological activity. J. Biol. Chem. 284 (9), 5968-5976.

Van de Walle, G.R., May, M.L., Sukhumavasi, W., von Einem, J., Osterrieder, N., 2007. Herpesvirus chemokine-binding glycoprotein $\mathrm{G}(\mathrm{gG})$ efficiently inhibits neutrophil chemotaxis in vitro and in vivo. J. Immunol. 179 (6), 4161-4169.

Viejo-Borbolla, A., Martin, A.P., Muniz, L.R., Shang, L., Marchesi, F., Thirunarayanan, N., Harpaz, N., Garcia, R.A., Apostolaki, M., Furtado, G.C., Mayer, L., Kollias, G. Alcami, A., Lira, S.A., 2010a. Attenuation of TNF-driven murine ileitis by intestinal expression of the viral immunomodulator CrmD. Mucosal Immunol. 3 (6), 633-644.

Viejo-Borbolla, A., Martinez-Martin, N., Nel, H.J., Rueda, P., Martin, R., Blanco, S. Arenzana-Seisdedos, F., Thelen, M., Fallon, P.G., Alcami, A., 2012. Enhancement of chemokine function as an immunomodulatory strategy employed by human herpesviruses. PLoS Pathog. 8 (2), e1002497.

Viejo-Borbolla, A., Munoz, A., Tabares, E., Alcami, A., 2010b. Glycoprotein G from pseudorabies virus binds to chemokines with high affinity and inhibits their function. J. Gen. Virol. 91 (Pt 1), 23-31.

von Einem, J., Smith, P.M., Van de Walle, G.R., O'Callaghan, D.J., Osterrieder, N. 2007. In vitro and in vivo characterization of equine herpesvirus type 1 (EHV-1) mutants devoid of the viral chemokine-binding glycoprotein G (gG). Virology 362 (1), 151-162.

Wang, D., Bresnahan, W., Shenk, T., 2004. Human cytomegalovirus encodes highly specific RANTES decoy receptor. Proc. Natl. Acad. Sci. U.S.A. 101 (47), 16642-16647

Webb, L.M., Clark-Lewis, I., Alcami, A., 2003. The gammaherpesvirus chemokine binding protein binds to the $\mathrm{N}$ terminus of CXCL8. J. Virol. 77 (15), 8588-8592.

Webb, L.M., Smith, V.P., Alcami, A., 2004. The gammaherpesvirus chemokine binding protein can inhibit the interaction of chemokines with glycosaminoglycans. FASEB J. 18 (3), 571-573

Weber, P.C., Levine, M., Glorioso, J.C., 1987. Rapid identification of nonessential genes of herpes simplex virus type 1 by Tn 5 mutagenesis. Science 236 (4801),576-579.

White, G.E., McNeill, E., Christou, I., Channon, K.M., Greaves, D.R., 2011. Site-directed mutagenesis of the CC chemokine binding protein 35K-Fc reveals residues essential for activity and mutations that increase the potency of CC chemokine blockade. Mol. Pharmacol. 80 (2), 328-336.

Xue, X., Lu, Q., Wei, H., Wang, D., Chen, D., He, G., Huang, L., Wang, H., Wang, X. 2011. Structural basis of chemokine sequestration by CrmD, a poxvirus-encoded tumor necrosis factor receptor. PLoS Pathog. 7 (7), e1002162.

Zhang, L., Derider, M., McCornack, M.A., Jao, S.C., Isern, N., Ness, T., Moyer, R., LiWang, P.J., 2006. Solution structure of the complex between poxvirus-encoded CC chemokine inhibitor vCCI and human MIP-1beta. Proc. Natl. Acad. Sci. U.S.A 103 (38), 13985-13990.

Zlotnik, A., Yoshie, O., 2000. Chemokines: a new classification system and their role in immunity. Immunity 12 (2), 121-127.

Zlotnik, A., Yoshie, O., Nomiyama, H., 2006. The chemokine and chemokine receptor superfamilies and their molecular evolution. Genome Biol. 7 (12), 243. 